Article

\title{
Resident Knowledge and Willingness to Engage in Waste Management in Delhi, India
}

\author{
Sudipta Bhawal Mukherji ${ }^{1, *}$, Makiko Sekiyama ${ }^{1}$, Takashi Mino ${ }^{1}$ and Bharati Chaturvedi ${ }^{2}$ \\ 1 Graduate Program in Sustainability Science-Global Leadership Initiative (GPSS-GLI), \\ Graduate School of Frontier Sciences, The University of Tokyo, 5-1-5, Kashiwanoha, Kashiwa City, \\ Chiba 277-8563, Japan; sekiyama@k.u-tokyo.ac.jp (M.S.); mino@mw.k.u-tokyo.ac.jp (T.M.) \\ 2 Chintan Environmental Research and Action group, 238, Sidhartha Enclave, New Delhi-110014, India; \\ bharati@chintan-india.org \\ * Correspondence: sudipta@sustainability.k.u-tokyo.ac.jp or sudipta.mukherji@gmail.com; \\ Tel.: +81-4-7136-4877
}

Academic Editor: Marc A. Rosen

Received: 7 August 2016; Accepted: 17 October 2016; Published: 21 October 2016

\begin{abstract}
Delhi generates about 8360 tons of municipal solid waste per day, and there is low compliance to rules regarding waste management. The objective of this paper was to understand the situation in Delhi with respect to the segregation, storage, collection, and disposal of household waste, and to assess the knowledge of the residents of Delhi, and their willingness to engage in solid-waste management. A stratified random sample, comprising 3047 respondents, was chosen for a questionnaire survey, covering all municipalities of Delhi, with socio-economic classification as the stratifying variable. Survey results indicate that $60 \%$ of residents do not know the difference between biodegradable and non-biodegradable waste, and only $2 \%$ of them segregate waste. Fifty-eight percent of respondents reported that the waste collector mixes the segregated waste, $97 \%$ of respondents reported that they sold items to an itinerant waste buyer, and $87 \%$ of households are covered by doorstep waste collection services. Abstract knowledge (general knowledge about waste management) is seen to have a significant correlation with willingness to engage in waste management. Differences between the socio-economic groups indicate that the highest (most educated and wealthy), as well as the lowest socio-economic category (least educated and poor), older age-groups, and women, have greater abstract knowledge. Socio-economic categories having higher abstract knowledge can be active participants in decentralized models of waste management.
\end{abstract}

Keywords: household municipal solid waste; resident knowledge; willingness to engage; waste segregation; waste collection; waste storage; waste disposal

\section{Introduction}

India is the fastest growing economy and the second most populated country in the world. The present annual quantity of solid waste generated in Indian cities has increased from six million tons, in 1947, to 48 million tons, in 1997, and to 90 million tons in 2009; this is expected to increase to 300 million tons by 2047 [1-3]. This massive increase in the amount of municipal solid waste (MSW) generated is because of changing lifestyles, food habits, and the standard of living of the urban population [4]. The characterization of MSW has indicated that the waste consists of $30 \%-45 \%$ organic matter, $6 \%-10 \%$ recyclables, and the rest is inert matter [5].

The collection of MSW is primarily the responsibility of corporations/municipalities. However, many municipalities have provided contracts to private waste management companies for secondary transportation from community bins to disposal sites. Others have employed non-governmental organizations (NGOs) and resident associations to supervise and arrange segregation and collection 
from the point of generation to collection points, by charging a collection fee to residents [6]. The community bin (dhalao) collection system is adopted in most cities in India. It is a primary storage facility, in the form of a waste receptacle, provided by a municipality [5]. On an average, there are about two to three collection points per square kilometer [4].

The inhabitants of Delhi generated about 4000 tons per day of MSW in 2000, 6800 tons per day in 2011 [7], and 8360 tons per day in 2015 [8]. The quantity of waste in Delhi is expected to increase to $17,000-25,000$ tons per day by 2021 [9]. Approximately $70 \%-80 \%$ of generated MSW is collected, and the rest is disposed of as open dumps on the streets. Only $9 \%$ of the collected MSW receives treatment through composting, which is the only treatment option, and the remaining mixed waste is disposed of in open landfills at the periphery of the city. Composting plants are not presently operating to their intended treatment capacities. In the absence of leachate and landfill gas collection systems, these landfills are a source of groundwater contamination, as well as of air pollution [4]. The low calorific value of waste, the presence of inert material, as well as construction and demolition waste in municipal solid waste, makes it inappropriate for incineration of waste for energy production. Therefore, the lack of waste segregation at the source of waste generation has been identified as a major hurdle in the further treatment and disposal of waste [10].

In the past, to facilitate the segregation of waste at the household level, the government introduced the MSWRules 2000 and the Bhagidari-a citizen-government partnership. The purpose of Bhagidari was to develop awareness, public participation, and to improve segregation and the primary collection of the waste [4]. However, it failed to introduce segregation due to a lack of public cooperation [11]. To facilitate the participation of the residents of Delhi, a greater generation of awareness and the promotion of motivation is essential [12].

The Municipal Corporation of Delhi recognizes that there is an extensive network of informal and formal stakeholders who collect waste, such as paper/cardboard, metals, glass, leather, plastic, rubber, textiles, etc. Recyclables are collected by rag pickers from dhalaos, or landfills, and are passed into the recycling stream. Households also directly sell recyclables to itinerant buyers. It is estimated that there are 80,000-100,000 rag pickers in Delhi, and, assuming that a rag picker picks up $50 \mathrm{~kg}$ of waste each day, it reduces the burden for treatment, as well as disposal, by 1200-1500 tons per day [13]. The total number of itinerant buyers in Delhi is estimated to be about 18,000-20,000 [13]. The quantity of waste sold to these buyers is unknown, but is expected to be, approximately, as much as that collected by rag pickers. Although the contributions of waste pickers and collectors for conserving the city's environment, and for reducing public cost, is significant [14], recycling by the informal sector is done in an unhygienic manner, causing air, groundwater, and soil pollution [13].

In Delhi, households are the largest source of solid waste generation [15], and there is very low compliance to rules regarding municipal solid waste management [7]. In such a situation, it becomes important to understand the level of knowledge possessed by the residents of Delhi regarding solid waste management. The importance of resident knowledge, and adequate facilities for public participation in waste management, has been established by studies conducted in other countries, such as Brazil [16], Italy [17,18], and Spain [19]. In addition, social and psychological factors may also play a crucial role in promoting public participation in waste management. In a case study conducted in a Greek island community, social factors were seen to influence perceptions and willingness to pay for solid waste management [20]. In the city of Nisshin, Japan, it was found that the expectation of personal empowerment, a sense of self-efficacy and solidarity, was the main determinant of the behavioral intention of citizen participation [21].

Several other studies have highlighted the waste management behavior of households in countries, such as UK [22,23], Iran [24], Malaysia [25], and Greece [26], using the framework of the theory of planned behavior, to understand the attitudes, subjective norms, intentions, and perceived behavioral controls of residents. A social survey conducted in Malaysia revealed that people have a positive intention in participating in source separation of food waste in the household, if they are given the knowledge, opportunities, and facilities needed regarding source separation [25]. A study in Iran 
indicated that educational material that targets moral obligation and action planning may be more effective in improving household waste reduction behavior [24]. A study done in the UK also suggests that a pro-recycling attitude is the major contributor to recycling behavior [22,23]. These attitudes are influenced by the availability of appropriate facilities and knowledge, apart from other factors, such as concern for the community and previous recycling experience. Research on resident knowledge, attitudes, and action regarding solid waste management in India is limited, and the influence of socio-economic factors on these attitudes has scarcely been investigated. In a study conducted in a town, in the southern state of Tamil Nadu in India, it was found that the monthly income of a household has a strong positive correlation with the disposal of vegetable waste. Monthly income has strong negative correlation with the presence of a dustbin at home and the reuse of items. The age of respondents is negatively correlated with waste segregation [27]. In the city of Bangalore, India, it was found that household income was positively correlated with a willingness to pay for waste management [28]. In another study conducted among the urban poor, in a slum of Jammu, it was revealed that a majority of the respondents had a high level of basic environmental awareness and that there were significant differences in environmental awareness levels among male and female respondents, but there were no significant differences among the different age groups [29]. A survey conducted in selected areas of the city of Coimbatore in South India, captured the perception of households, but did not explore the differences among socio-economic categories [30]. All of these studies have suggested a need for improving the knowledge of residents regarding waste management. However, these studies explore only a few aspects of knowledge and attitude. Moreover, the attitude and culture of the residents of the capital city of Delhi are very different from those explored in the existing literature.

Knowledge has been seen as a key variable affecting environmental action [31,32]. It has been argued that higher levels of environmentally relevant knowledge play a significant role in modifying environmental behavior [33,34]. Schahn and Holzer [35] follow two definitions of knowledge in their research on recycling: abstract knowledge (AK), which focuses on awareness of general environmental issues, and concrete knowledge (CK), which evaluates awareness of local services, for example, recycling services [36]. In this research, we modify these definitions further, and understand AK as knowledge regarding general issues regarding waste management, and define CK as knowledge regarding issues specific to waste management in Delhi. Knowledge is an important predictor of behavior, as a lack of knowledge will lead to a decline in self-efficacy, and then lead to the feeling that the individual cannot participate because they lack the knowledge required to take part [36]. In the present research, we will utilize these definitions of abstract knowledge and concrete knowledge.

The objectives of the present study are summarized as follows. Firstly, this research seeks to explain the situation in Delhi with respect to segregation, storage, collection, and disposal of solid waste. Secondly, an attempt is made to understand the relationships between: (1) abstract knowledge and the willingness to engage in waste management; (2) concrete knowledge and willingness to engage in solid-waste management; and (3) willingness to engage in solid-waste management and waste segregation. Thirdly, this research also explores how resident knowledge varies among different socio-economic categories. This research does not explore all other situational and psychological factors that determine behavior, as the focus of this study is to explore resident knowledge regarding waste management.

\section{Materials and Methods}

\subsection{Study Area}

A questionnaire survey was conducted in Delhi, the capital of India. The city has a population of 16 million [37], an increase from 13 million in the 2001 census. The total area of Delhi is $1483 \mathrm{sq} . \mathrm{km}$. The population density of Delhi is 11,320 per sq. $\mathrm{km}$. The total population growth in this decade was 
$21.2 \%$, while, in the previous decade, it was $46.3 \%$. The population of Delhi formed $1.39 \%$ of the total population of India in 2011.

The Municipal Corporation of Delhi (MCD), New Delhi Municipal Council (NDMC), and Delhi Cantonment Board (DCB) are the three municipal entities responsible for MSW management in Delhi. The Municipal Corporation of Delhi has been trifurcated into three smaller municipal corporations-the North Delhi Municipal Corporation, South Delhi Municipal Corporation, and East Delhi Municipal Corporation. A map of Delhi is provided in Figure 1 [38].

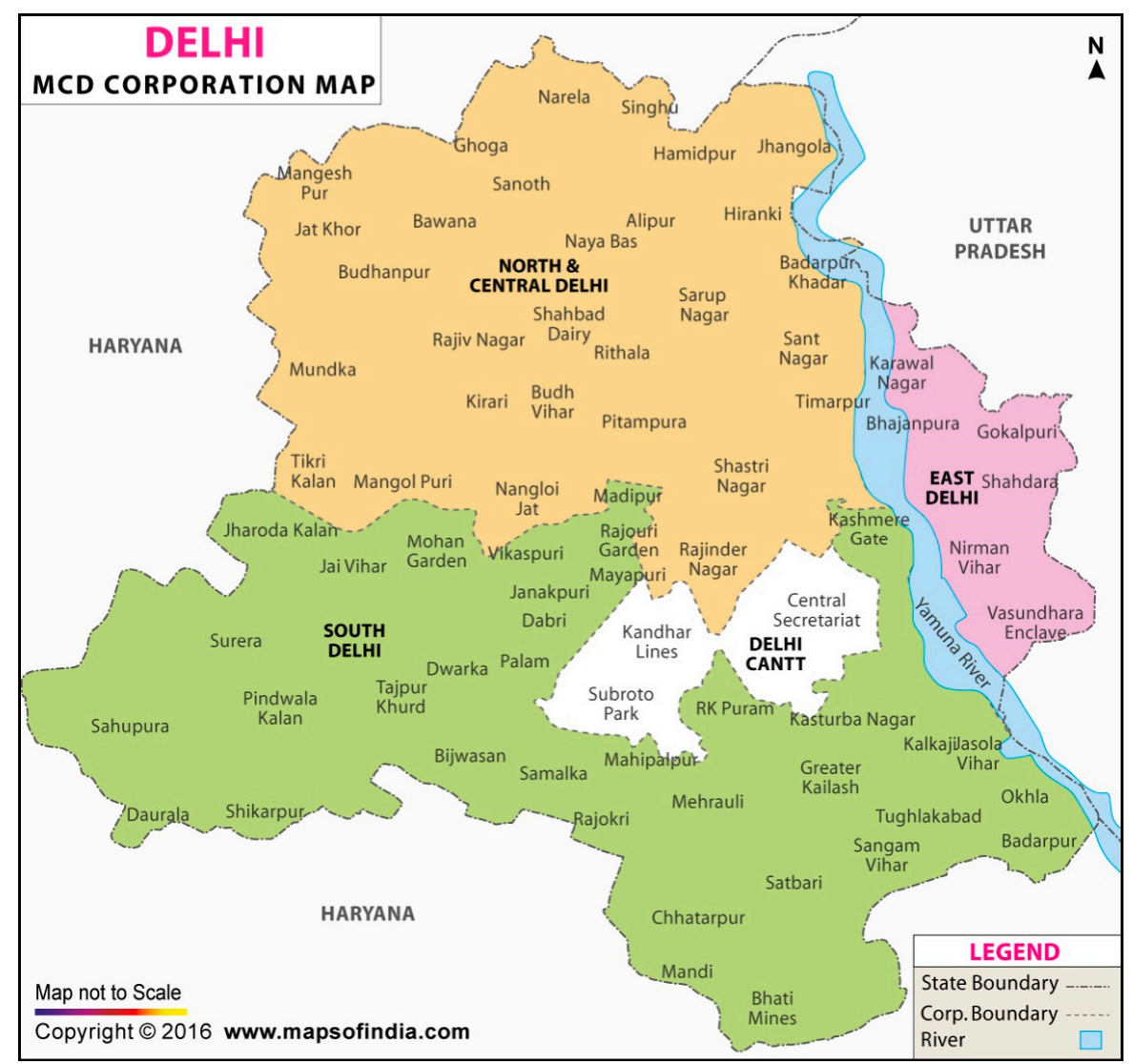

Figure 1. Map of Delhi.

\subsection{Questionnaire Survey Method}

The questionnaire was prepared in English and Hindi, the official languages of India. The questionnaire was comprised of two parts; the first part had questions on demographic information, and the second part was comprised of questions on solid-waste management, with sub-sections on waste generation, storage, segregation, doorstep waste collection, waste disposal, payment for waste management, and knowledge, attitudes, and perceptions regarding waste management in Delhi. Each questionnaire had 75 questions. Selected questions were used for the purpose of this research. The questionnaire survey was conducted in October and November, 2013, by a team of trained enumerators. Before the survey, the enumerators were provided with an orientation regarding the purpose of the research and were given detailed instructions regarding the method of asking questions to the respondents. The enumerators visited each household, and filled in the questionnaires by interviewing the respondents.

\subsection{Sampling Method}

Based on stratified sampling, 3047 households were chosen as the respondents of this study. From each household, one member (mainly a household head) responded to our questionnaire. 
The socio-economic category is the stratifying variable. Respondents were selected from socio-economic categories, namely A, B, C, and D, from the four municipal entities (East Delhi, North Delhi, South Delhi, and New Delhi). The counts for the respondents chosen from different municipalities and socio-economic categories are given in Table 1.

Table 1. Actual sample distribution across municipalities and socio-economic classification (SEC) categories.

\begin{tabular}{ccccccc}
\hline Municipalities & A & B & C & D & Unknown & Total \\
\hline East Delhi & 296 & 144 & 63 & 16 & 0 & 519 \\
North Delhi & 579 & 291 & 197 & 95 & 176 & 1338 \\
South Delhi & 331 & 290 & 199 & 38 & 16 & 874 \\
New Delhi & 79 & 114 & 88 & 20 & 15 & 316 \\
Total & 1285 & 839 & 547 & 169 & 207 & 3047 \\
\hline
\end{tabular}

Note: $\mathrm{A}$ is the highest socio-economic category and $\mathrm{D}$ is the lowest socio-economic category. $\mathrm{A}$ to $\mathrm{D}$ is in decreasing order.

This research relied on the socio-economic classification (SEC) system, which is widely used to understand market segmentation and consumer behavior in India. The SEC system has been developed by the Market Research Society of India (MRSI) [39]. It uses two variables to classify households. The first variable is the education of the chief wage earner (CWE): the CWE is defined as the person who contributes the maximum amount to the expenses of the household, sometimes also referred to as the head of the household. The SEC classification system relies on the following seven categories to capture the education level of the CWE: illiterate; literate but no formal schooling or schooling up to four years; schooling between five and nine years; senior secondary or higher secondary education; some college (including a diploma) but not a graduate; graduate or post graduate (general); and graduate or post graduate (professional). The second variable is the number of consumer durables in the household: The list of durables has 11 items-electricity connection, ceiling fan, LPG (liquefied petroleum gas) stove, two wheeler vehicle, color television, refrigerator, washing machine, personal computer, car, air conditioners, and agricultural land. Based on a matrix of education levels and number of durables, the SEC classification of a household is determined [39].

\subsection{Statistical Analysis}

The Cronbach's alpha test was applied to evaluate the reliability of the questions with the aim of ensuring that each question under a variable all measured the same underlying attributes. Spearman's rank correlation coefficient was calculated in order to examine the relationships between: (1) abstract knowledge and willingness to engage in waste management; (2) concrete knowledge and willingness to engage in waste management; and (3) willingness to engage in waste management and waste segregation. For AK, differences among several socio-economic factors were tested; the differences between the genders were tested using the Mann Whitney's U-test, and differences among the age-groups and socio-economic categories were tested using the Kruskal-Wallis test. For age-groups and socio-economic categories, further analyses, testing the difference between each group, were conducted using the Mann Whitney's U-test and corrected by the Bonferroni test. All analyses were performed using the Statistical Package for Social Science (SPSS) software package (Version 20.0, SPSS Inc., Chicago, IL, USA).

\section{Results and Discussion}

\subsection{Characteristics of the Respondents}

The characteristics of respondents are given in Table 2. In our sample, $54 \%$ were male and $46 \%$ percent were female. Among the age categories, the largest number of respondents was from the 21-40 age-group (59\%). Regarding household size, 56\% of the households had five to eight members. 
Senior secondary or higher secondary, and some college, comprised $55 \%$ of the population. Regarding the socio-economic category, $42 \%$ of respondents were from the highest category (A category). Overall, based on the comparison of the sample against the underlying population, based on demographic information, such as education, gender ratio, age structure, and household size size, we can conclude that our sample provides a fairly good representation of Delhi's population. This has been shown in Table 2, by comparing the characteristics of respondents, with data from the 2011 census [37].

Table 2. Characteristics of respondents $(\mathrm{N}=3047)$.

\begin{tabular}{|c|c|c|c|}
\hline Category & Questionnaire Content & Percentage & 2011 Census \\
\hline \multirow{2}{*}{ Gender } & Male & 54 & 53 \\
\hline & Female & 46 & 47 \\
\hline \multirow{4}{*}{ Age Categories } & Less than 21 & 9 & 17 \\
\hline & $21-40$ & 59 & 51 \\
\hline & $41-60$ & 27 & 25 \\
\hline & Above 60 & 6 & 8 \\
\hline \multirow{4}{*}{ Household Size } & Less than 3 & 4 & 11 \\
\hline & $3-4$ & 32 & 38 \\
\hline & $5-8$ & 56 & 41 \\
\hline & More than 8 & 9 & 10 \\
\hline \multirow{4}{*}{ Respondent Education } & Illiterate & 6 & 15 \\
\hline & Literate and Schooling between 5 and 9 years & 20 & 30 \\
\hline & $\begin{array}{l}\text { Senior Secondary or Higher Secondary } \\
\text { and Some college including diploma }\end{array}$ & 55 & 32 \\
\hline & Graduate or Post Graduate general or professional & 19 & 23 \\
\hline \multirow{5}{*}{$\begin{array}{l}\text { Socio-Economic } \\
\text { Classification }\end{array}$} & A (highest category) & 42 & - \\
\hline & $\mathrm{B}$ & 28 & - \\
\hline & $\mathrm{C}$ & 18 & - \\
\hline & D (lowest category) & 6 & - \\
\hline & Not available & 7 & - \\
\hline \multirow{5}{*}{ Municipality } & North Delhi Municipal Corporation & 44 & - \\
\hline & South Delhi Municipal Corporation & 27 & - \\
\hline & East Delhi Municipal Corporation & 17 & - \\
\hline & New Delhi Municipal Council & 10 & - \\
\hline & Not available & 2 & - \\
\hline
\end{tabular}

\subsection{Situation in Delhi: Waste Storage, Collection and Disposal}

\subsubsection{Waste Storage and Disposal}

Table 3 shows the situation of waste storage and disposal in Delhi. It shows that only $2 \%$ of the households in Delhi segregate waste. One of the major reasons for the lack of segregation at the source was that the waste collector mixes segregated waste, as was reported by $58 \%$ of the respondents. Regarding waste storage, $75 \%$ of residents store their waste in a bin inside the house, and $19 \%$ of residents store their waste in a plastic bag inside the house. Ninety-seven percent of the respondents reported that they sell items to the Kabariwala, that is, an itinerant waste buyer. The main items sold to Kabariwalas were newspapers (43\%), glass bottles (18\%), and plastic oil cans $(22 \%)$. The reasons for which they sell these items to the Kabariwala are for the price that they get in exchange for the item $(65 \%)$, followed by concern for the environment (34\%). Regarding waste disposal, it was found that $80 \%$ of respondents have a community bin/dhalao in their area. Sixty-three percent mentioned that the community bin/dhalao is cleared on a daily basis. Seventy-eight percent mentioned that roadside open plot dumping is practiced in their locality.

This implies that, for segregation to begin, the mixing of segregated waste by the doorstep waste-collector needs to stop. In addition, residents were segregating their waste to the extent that it had economic value to the Kabariwala. 
Table 3. Situation in Delhi-waste storage and disposal.

\begin{tabular}{ccc}
\hline \multicolumn{1}{c}{ Category } & Questionnaire Content & Percentage (\%) \\
\hline Segregation & Segregation Rate & 2 \\
\hline Reason for not segregating the waste & Because waste collector mixes segregated waste & 58 \\
\hline \multirow{3}{*}{ Waste storage } & Bin inside the house & 75 \\
& Reuse a plastic bag and keep inside the house & 19 \\
& Store outside the house by the roadside & 6 \\
Kabariwala & Store in a cement bin outside the house & 0 \\
\hline \multirow{2}{*}{ What is sold to Kabariwala? } & Sell items to Kabariwala ${ }^{1}$ & 97 \\
& Newspaper & 43 \\
& Magazine & 4 \\
& Cardboard & 3 \\
& Glass bottles & 18 \\
Reasons for selling to Kabariwala? & Dalda tins ${ }^{2}$ & 5 \\
& Pet bottles & 4 \\
& Plastic oil cans & 22 \\
\cline { 2 - 3 } & Convenience & 1 \\
& Household tradition & 65 \\
\hline \multirow{2}{*}{ Waste disposal } & Environment & 1 \\
& Is your community bin cleared on a daily basis (Yes) & 34 \\
\hline & Is roadside open plot dumping practiced in the locality (Yes) & 63 \\
\end{tabular}

${ }^{1}$ Itinerant waste buyer who buys recyclables from households; ${ }^{2}$ Metallic containers used for storing clarified butter.

\subsubsection{Doorstep Waste Collection}

Table 4 shows the situation of doorstep waste collection in Delhi. Eighty-seven percent of respondents answered that someone collects waste from their house. Among them, $72 \%$ was collected by the municipality. Eighty-seven percent of respondents mentioned that someone collects waste from their house on a daily basis. Among those who have a doorstep collection service, $44 \%$ pay for the service. Forty-four percent pay the local sweeper, and 59\% said that the amount that they paid was INR 31-50.

Table 4. Situation in Delhi-doorstep waste collection.

\begin{tabular}{|c|c|c|}
\hline Category & Questionnaire Content & Percentage $(\%)$ \\
\hline Doorstep waste collection & Does anyone collect waste from your house (Yes) & 87 \\
\hline \multirow{7}{*}{ Who collects waste from your house? } & Municipality & 72 \\
\hline & Private Contractor & 6 \\
\hline & Non-Governmental Organization & 2 \\
\hline & Individual person not connected with any organization & 13 \\
\hline & Residents Welfare Association & 1 \\
\hline & I don't know & 6 \\
\hline & Other & 1 \\
\hline \multirow{5}{*}{ How frequently is waste collected? } & Daily & 87 \\
\hline & Alternate days & 4 \\
\hline & Twice a week & 8 \\
\hline & Once a week & 0 \\
\hline & Occasionally & 1 \\
\hline Payment for doorstep waste collection? & Do you pay for doorstep waste collection (Yes) & 44 \\
\hline \multirow{3}{*}{ To whom do you pay? } & Local sweeper & 44 \\
\hline & Collector themselves & 29 \\
\hline & Representative of the waste collector & 28 \\
\hline \multirow{4}{*}{$\begin{array}{l}\text { How much do you pay monthly for } \\
\text { doorstep waste collection? }\end{array}$} & INR $31-50^{1}$ & 59 \\
\hline & INR 51-100 & 19 \\
\hline & Less than INR 30 & 22 \\
\hline & Over INR 100 & 0 \\
\hline
\end{tabular}

\footnotetext{
${ }^{1}$ INR is the ISO Code for Indian Rupee, the official currency of the Republic of India.
} 


\subsection{Abstract Knowledge, Concrete Knowledge, and Willingness to Engage in Waste Management}

In the analysis of this survey, resident knowledge regarding waste management was divided into two types-abstract knowledge (general awareness about waste management) and concrete knowledge (specific knowledge about waste management in Delhi). The questions in each category and the percentage of appropriate responses are shown in Table 5. It is important to note that, in the abstract knowledge of residents, $60 \%$ of residents do not know the difference between biodegradable and non-biodegradable waste. The significance of this categorization is that biodegradable waste can be composted, and non-biodegradable waste can be further segregated and recycled or processed [40]. The statements on abstract knowledge (Table 5) show that the majority of residents lack awareness regarding the threat of environmental degradation due to poor waste management. Regarding concrete knowledge, it is important to note that $98 \%$ respondents answered correctly the statement on "Kabaris and wastepickers recycle most of the municipal solid waste generated." In another question in the survey about the opinion of residents, $95 \%$ respondents agreed with the statement "I think wastepickers/Kabaris need to be organized." It is interesting to note that residents believe that the condition of wastepickers should be improved and that they should have access to a better quality of life. The reliability coefficient, or alpha value for each factor, is also shown in Table 5. The scores of abstract knowledge, concrete knowledge, and willingness to engage, have an alpha value of approximately 0.7 , which makes it appropriate for use in further statistical analysis.

Table 5. Questionnaire items on respondent's willingness and knowledge on waste management, and their reliability coefficients.

\begin{tabular}{|c|c|c|c|}
\hline Factors & Questions & $\begin{array}{l}\text { Reliability } \\
\text { Coefficient }\end{array}$ & $\begin{array}{c}\text { Percentages of } \\
\text { Appropriate } \\
\text { Responses (\%) }\end{array}$ \\
\hline \multirow{4}{*}{$\begin{array}{l}\text { Willingness to } \\
\text { Engage }\end{array}$} & $\begin{array}{l}\text { I am willing to segregate my waste to make recycling } \\
\text { more efficient and to safeguard the health of workers. }\end{array}$ & \multirow{4}{*}{0.712} & 74 (Yes) \\
\hline & $\begin{array}{l}\text { I am ready to accept a lower price for my old } \\
\text { paper/plastic/glass products if it is disposed in an } \\
\text { environmentally friendly and socially } \\
\text { responsible manner. }\end{array}$ & & 80 (Yes) \\
\hline & I am willing to start composting. & & 71 (Yes) \\
\hline & It is practical for me to live without plastic bags. & & 81 (Yes) \\
\hline \multirow{5}{*}{$\begin{array}{c}\text { Abstract } \\
\text { Knowledge }\end{array}$} & $\begin{array}{l}\text { Do you know the difference between biodegradable } \\
\text { and non-biodegradable waste. }\end{array}$ & \multirow{5}{*}{0.674} & 60 (No) \\
\hline & $\begin{array}{l}\text { Reducing consumption, and therefore waste, is not an } \\
\text { option for India at this moment on its path towards } \\
\text { economic progress. }\end{array}$ & & 49 (False) \\
\hline & $\begin{array}{l}\text { Burning of waste in a neighborhood is safe as long as it } \\
\text { is outside the home. }\end{array}$ & & 58 (False) \\
\hline & Improper waste management causes pollution. & & 95 (Yes) \\
\hline & Reusing more things is better than buying new things. & & 77 (Yes) \\
\hline \multirow{4}{*}{$\begin{array}{l}\text { Concrete } \\
\text { Knowledge }\end{array}$} & Are you aware of the condition of landfills in your city. & \multirow{4}{*}{0.767} & 31 (Yes) \\
\hline & $\begin{array}{l}\text { Should waste generators pay based on the type of } \\
\text { waste they throw away. }\end{array}$ & & 46 (Yes) \\
\hline & $\begin{array}{l}\text { Should waste generators pay depending on how much } \\
\text { they throw away. }\end{array}$ & & 44 (Yes) \\
\hline & $\begin{array}{l}\text { Kabariwalas and wastepickers recycle most municipal } \\
\text { solid waste generated. }\end{array}$ & & 98 (True) \\
\hline
\end{tabular}

As shown in Figure 2, the relationship between abstract knowledge and willingness to engage in waste management was investigated using Spearman's correlation coefficient. There was a significant 
positive correlation between the variables, $\mathrm{r}=0.279, \mathrm{n}=3047, p<0.001$, with a high level of abstract knowledge associated with a high level of engagement in waste management. The relationship between concrete knowledge and willingness to engage in waste management was investigated using Spearman's correlation coefficient. There was no significant correlation between the variables, $r=0.013$ and $n=3047$. The relationship between willingness to engage and waste segregation was also investigated using Spearman's correlation coefficient. There was a weak negative correlation between the variables, $\mathrm{r}=-0.086, p<0.001$.

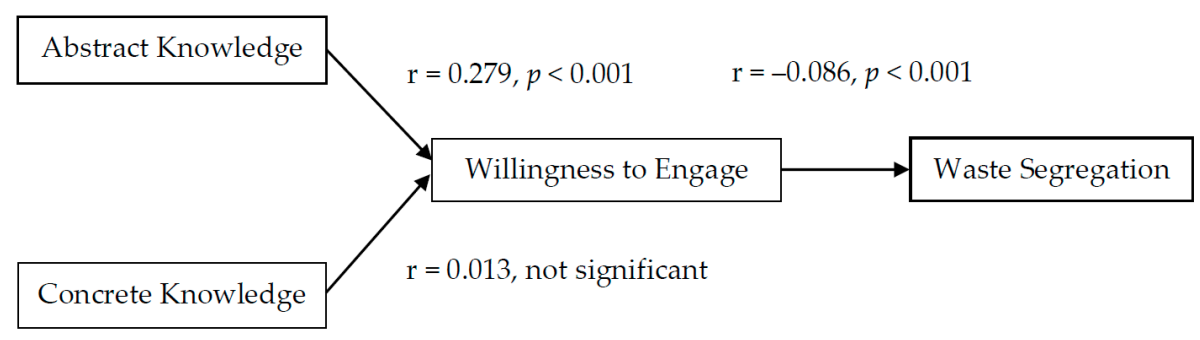

Figure 2. Relationship between abstract knowledge, concrete knowledge, willingness to engage and waste segregation ( $r=$ Spearman's correlation coefficient; $p=$ level of significance).

As indicated in Table 5, 60\% of residents did not know the difference between biodegradable and non-biodegradable waste. The correlation results, as shown in Figure 2, indicate that abstract knowledge is significantly related to willingness to engage in waste management. This is in accordance with the view that more a general education and information about larger issues of waste management are needed in order to explain to the public the need for the acceptance of a broader responsibility towards waste disposal [41]. Therefore, it was judged that identifying the differences between socio-economic groups with regard to the abstract knowledge of respondents was of significance.

\subsection{Difference of Abstract Knowledge among Different Socio-Economic Groups}

Table 6 shows the differences in Abstract Knowledge among different socio-economic groups, with the exception of household size and municipality. For groups with more than two categories, the numbers with superscripts, having any letter of the alphabet in common are not significantly different from each other, and only numbers with superscripts with no letters in common have significant differences.

Table 6. Difference of abstract knowledge among different socio-economic groups.

\begin{tabular}{cccc}
\hline Categories & Questionnaire Content & Mean Score $^{\mathbf{2}}$ & Significance $^{\mathbf{1}}$ \\
\hline \multirow{2}{*}{ Gender } & Male & 3.08 & 0.000 \\
& Female & 3.38 & \\
\multirow{2}{*}{ Age } & Less than 21 & $2.94^{\mathrm{a}}$ & 0.000 \\
& $21-40$ & $3.18^{\mathrm{ab}}$ & \\
& $41-60$ & $3.31^{\mathrm{bc}}$ & \\
Socio-Economic & Above 60 & $3.58^{\mathrm{c}}$ & \\
Category & $\mathrm{A}$ & $3.55^{\mathrm{b}}$ & \\
& $\mathrm{B}$ & $3.07^{\mathrm{a}}$ & \\
& $\mathrm{C}$ & $3.12^{\mathrm{a}}$ & \\
& $\mathrm{D}$ & $3.79^{\mathrm{b}}$ &
\end{tabular}

${ }^{1}$ Difference between the two groups was tested using the Mann Whitney's U-test. Differences among the four groups were tested using Kruskal-Wallis test; ${ }^{2}$ For the age and socio-economic categories, further comparisons between the groups were tested using the Mann Whitney's U-test and corrected by the Bonferroni test. Values sharing the same letter were not significantly different from each other. 
The analysis revealed that females had higher abstract knowledge $(p<0.001)$. This may be because women have a closer engagement with waste management at the household level [42]. Studies in Uganda, Pakistan, Bangladesh, and Vietnam also found that women were more involved in source separation than men in the household [43-45]. The situation in traditional, Southern Italian society is also similar [46]. This shows that women have a better understanding of, and knowledge about, waste management.

It was also found that the older age-group had higher abstract knowledge $(p<0.001)$, because the older generation valued resources and their optimum utilization, coming from the pre-liberalization era of India. This may be because older persons have more time to perform household waste reduction behaviors, or they have a greater desire to conserve resources for future generations. These results are similar to previous studies $[24,42,47,48]$, which showed a positive relationship between age and household waste behavior. Younger age-groups showed a lower level of awareness, similar to a previous study [18].

The abstract knowledge of younger age-groups was the lowest, suggesting a need for increasing the abstract knowledge of these groups. Dissemination of educational materials in schools or universities, and creating advertisements that target younger generations, would be effective strategies for increasing awareness on waste management among younger age-groups [49].

Socio-economic categories A and D have a higher abstract knowledge. This seems plausible because lower socio-economic groups have a closer engagement with waste management, as domestic helpers in households, maidservants [50], cleaning staff, and informal recyclers. The lower socio-economic category also understands and values the importance of resources, as they sell more recyclables to earn money [44]. The highest socio-economic category is the most educated category, therefore, they are bound to have greater knowledge [42,46].

\subsection{Applicability of the Results to the Existing Waste Management System}

More effort needs to be made in increasing abstract knowledge regarding waste management of the less-aware categories of residents (middle class and younger people), as that is the first step in improving awareness and changing the attitudes of people, and involving them in participatory decentralized models of waste management.

The socio-economic categories with higher abstract knowledge have been seen to be more active in waste management at a local level. In community-based models of waste management, monitoring and supervision by the local residents association, comprised of the elderly and women, has been well exemplified by the Defense Colony Residents Welfare Association (RWA) working with an NGO called Toxics Link, in a residential area in the southern part of Delhi [51]. This model of decentralized segregation and composting employs rag pickers in the task of secondary segregation and composting, after waste collection. RWA has conducted awareness generation on solid-waste management using door-to-door meetings with residents and by distributing information, education, and communication (IEC) material, organizing orientation programs on solid-waste management for the stakeholders, conducting capacity-building workshops with waste collectors, and training waste collectors on the segregation and composting of garbage. RWA has regularly imparted awareness to domestic helpers and residents in order to emphasize segregation and waste reduction at the source, so that a minimum amount of waste goes to a landfill. Improved segregation of waste can be facilitated by the construction of material recovery facilities (MRF), as suggested by Solid Waste Management Rules 2016 [40]. Discussions with experts have revealed that the local community bin (dhalao) could be converted into dry waste collection and sorting centers, and serve as a site for decentralized composting.

Exnora Green Pammal, Solid Waste Collection and Handling (SWaCH), in Pune, and Advanced Locality Management (ALM), in Mumbai, are other cases from India that exemplify the higher awareness or greater involvement of women and the informal recycling sector. There are several success stories about the contribution of the informal recycling sector, as well as the importance 
of public participation, in waste management in many other countries, such as Bangladesh [50], Pakistan [52], Brazil [53], Ghana [54], India [55], and Cairo, Egypt [56].

Therefore, it would be significant to involve residents with higher abstract knowledge in the monitoring and supervision, and the informal sector for segregation and composting. In this work, we have tried to identify segments of the population that are more amenable to behavioral change. This method of focusing strategies on segments of the population that have a higher likelihood to change their behaviors, is a possible mechanism for improvement of participation in the household with respect to recycling [57]. Such information is particularly significant in India in the current context, as the Clean India Mission is gaining momentum.

\section{Recommendations and Conclusions}

The primary problem regarding waste management in Delhi is a lack of segregation at the source. This is inevitable, as most residents do not know the difference between biodegradable and non-biodegradable waste. Beginning at the household level, each household should segregate waste into two bins (dry/non-biodegradable and wet waste/biodegradable). This is logically possible as most households in this study had a bin inside the house (Table 3). Further segregation into biodegradable, non-biodegradable, and domestic hazardous waste, as suggested in Solid Waste Management Rules 2016, will only be possible once residents recognize the basic difference between biodegradable and non-biodegradable waste. It should be noted that preventing mixing of waste by doorstep waste collectors is very important, as the current survey revealed that people do not segregate their waste because waste collectors mix the waste during collection (Table 3). Old newspapers are sold to Kabariwalas, or itinerant waste buyers, as they can be stored in a convenient location in the house, taking up little space in a corner of the house, as they do not require cleaning before storage, unlike glass bottles/plastic oil cans. Financial incentives or extrinsic motivation drives residents to segregate their waste, since a majority of the respondents answered that the reasons for selling waste to Kabariwala was due to the value of the waste (Table 3).

The Residents Welfare Association (comprising women and the elderly) could also monitor and supervise segregation, recycling, and composting in their residential areas and ensure that the doorstep collector collects segregated waste from households, as the survey shows that a majority of the households already have a doorstep collection service. Such an arrangement would involve the active participation of groups with higher abstract knowledge (elderly, women, and the lowest and highest socio-economic categories). Community-based management programs have successfully diverted waste from landfills, as exemplified in Thailand [58]. Replication of such models would go a long way in ensuring the economic, environmental, and social sustainability of waste management in Delhi.

As revealed in discussions with NGO representatives in Delhi, in the past, there has been a failure in reaching out to the common people due to the absence of adequate and appropriate advocacy tools and sustained awareness campaigns, targeting different sections of the population. It would be essential to impart general knowledge (abstract knowledge) regarding waste management to residents, since abstract knowledge is significantly correlated with a willingness to engage in waste management. In order to encourage source segregation there needs to be interesting awareness campaigns focusing on waste management as a public health issue, and highlighting its impact on environmental pollution. In addition, there should be agreements with waste workers, such as incentive mechanisms and penalties for non-compliance, as suggested in the Solid Waste Management Rules 2016 [40]. Sliding fiscal incentives, based on non-segregation, may go a long way in ensuring that residents segregate their waste. A household that segregates $80 \%$ of the days, should be asked to pay less doorstep collection fee than a household that segregates $50 \%$ of the days. In addition, there can be non-monetary incentives, such as rewards for households that segregate their waste, or for residential areas which have a high percentage of segregating households. Residents need to see the benefits of source segregation of waste in order to be encouraged to segregate; for example, if they see their dry waste getting recycled and 
compost being generated out of their wet waste (and that compost is being used in their gardens) then they may understand the value of segregation.

To improve waste management in Delhi, it would be important to ensure the involvement of all stakeholders. NGOs and RWAs can help in conducting awareness campaigns and facilitating doorstep collection in a systematic manner. Additionally, the government can provide space and facilities for MRFs. Private waste management companies can help in the regular transport of waste, and in the processing of hazardous domestic waste. Companies manufacturing products with potential for extended producer responsibility can collaborate with the Kabariwala network in order to facilitate proper collection. Segregation at the source would significantly reduce the burden on waste collection vehicles, from community bins to landfills, as they would only be responsible for the transportation of hazardous waste to a centralized processing facility, and to take inert waste to landfills. Further research can elaborate the specific details of such a model for Delhi.

Acknowledgments: The data for this paper were collected as a part of a research project conducted by Chintan-Environmental Research and Action Group, and GIZ (Deutsche Gesellschaft für Internationale Zusammenarbeit), Delhi, India. The authors express their sincere gratitude to Chintan, GIZ, and the Graduate Program in Sustainability Science-Global Leadership Initiative, The University of Tokyo, for supporting this research.

Author Contributions: Sudipta Bhawal Mukherji participated in data collection and designing of the questionnaire survey, analyzed the data and wrote the research article. Makiko Sekiyama and Takashi Mino supervised the research, data analysis, and writing of the research article. Bharati Chaturvedi designed, organized and conducted the questionnaire survey.

Conflicts of Interest: The authors declare no conflicts of interest.

\section{References}

1. Gupta, N.; Yadav, K.K.; Kumar, V. A review on current status of municipal solid waste management in India. J. Environ. Sci. 2015, 37, 206-217. [CrossRef] [PubMed]

2. Sharholy, M.; Ahmad, K.; Mahmood, G.; Trivedi, R.C. Development of Prediction Models for Municipal Solid Waste Generation for Delhi City. In Proceedings of National Conference of Advances in Mechanical Engineering; Jamia Millia Islamia: New Delhi, India, 2006.

3. The Energy and Resources Institute. TEDDY (TERI Energy Data Directory \& Yearbook); The Energy and Resources Institute: New Delhi, India, 2010.

4. Talyan, V.; Dahiya, R.P.; Sreekrishnan, T.R. State of municipal solid waste management in Delhi, the capital of India. Waste Manag. 2008, 28, 1276-1287. [CrossRef] [PubMed]

5. Kumar, S.; Bhattacharyya, J.K.; Vaidya, A.N.; Chakrabarti, T.; Devotta, S.; Akolkar, A.B. Assessment of the status of municipal solid waste management in metro cities, state capitals, class I cities, and class II towns in India: An insight. Waste Manag. 2009, 29, 883-895. [CrossRef] [PubMed]

6. Sharholy, M.; Ahmad, K.; Mahmood, G.; Trivedi, R.C. Municipal solid waste management in Indian cities-A review. Waste Manag. 2008, 28, 459-467. [CrossRef] [PubMed]

7. Central Pollution Control Board. Status Report on Municipal Solid Waste Management; Central Pollution Control Board: Delhi, India, 2013.

8. Government of Delhi Waste Management. Available online: http://www.delhi.gov.in/wps/wcm/connect/ environment/Environment/Home/Environmental+Issues/Waste+Management (accessed on 3 June 2016).

9. Government of NCT Delhi; Government of India. Delhi Urban Environment and Infrastructure Improvement Project (DUEIIP) Delhi 21; Government of India: Delhi, India, 2001.

10. Planning Commission. Report of the Task Force on Waste to Energy (Volume I): In the Context of Integrated Municipal Solid Waste Management; Planning Commission: New Delhi, India, 2014.

11. Singh, J.; Ramanathan, A.L. Solid Waste Management. Present and Future Challenges; I.K. International Publishing House: Bangalore, India, 2010; pp. 126-128.

12. Anand, S. Solid Waste Management; Mittal Publications: New Delhi, India, 2010; pp. 215-217.

13. East Delhi Muncipal Corporation Solid Waste Transportation Management System. Available online: http://mcdonline.gov.in/tri/edmc_mcdportal/dems / (accessed on 3 June 2016). 
14. Hayami, Y.; Dikshit, A.K.; Mishra, S.N. Waste pickers and collectors in Delhi: Poverty and environment in an urban informal sector. J. Dev. Stud. 2006, 42, 41-69. [CrossRef]

15. Municipal Corporation of Delhi. Feasibility Study and Master Plan for Optimal Waste Treatment and Disposal for the Entire State of Delhi Based on Public Private Partnership Solutions. Volume 6: Municipal Solid Waste Characterisation Report; Municipal Corporation of Delhi: Delhi, India, 2004.

16. Bringhenti, J.R.; Günther, W.M.R. Social participation in selective collection program of municipal solid waste. Eng. Sanit. Ambient. 2011, 16, 421-430. [CrossRef]

17. Castagna, A.; Casagranda, M.; Zeni, A.; Girelli, E.; Rada, E.C.; Ragazzi, M.; Apostol, T. 3R'S from citizens point of view and their proposal from a case-study. UPB Sci. Bull. Ser. D Mech. Eng. 2013, 75, 253-264.

18. De Feo, G.; De Gisi, S. Public opinion and awareness towards MSW and separate collection programmes: A sociological procedure for selecting areas and citizens with a low level of knowledge. Waste Manag. 2010, 30, 958-976. [CrossRef] [PubMed]

19. Junquera, B.; Del Brío, J.Á.; Muñiz, M. Citizens' attitude to reuse of municipal solid waste: A practical application. Resour. Conserv. Recycl. 2001, 33, 51-60. [CrossRef]

20. Jones, N.; Evangelinos, K.; Halvadakis, C.P.; Iosifides, T.; Sophoulis, C.M. Social factors influencing perceptions and willingness to pay for a market-based policy aiming on solid waste management. Resour. Conserv. Recycl. 2010, 54, 533-540. [CrossRef]

21. Maeda, H.; Hirose, Y. Expectation of empowerment as a determinant of citizen participation in waste management planning. Jpn. Psychol. Res. 2009, 51, 24-34. [CrossRef]

22. Tonglet, M.; Phillips, P.S.; Read, A.D. Using the Theory of Planned Behaviour to investigate the determinants of recycling behaviour: A case study from Brixworth, UK. Resour. Conserv. Recycl. 2004, 41, 191-214. [CrossRef]

23. Davis, G.; Phillips, P.S.; Read, A.D.; Iida, Y. Demonstrating the need for the development of internal research capacity: Understanding recycling participation using the Theory of Planned Behaviour in West Oxfordshire, UK. Resour. Conserv. Recycl. 2006, 46, 115-127. [CrossRef]

24. Pakpour, A.H.; Zeidi, I.M.; Emamjomeh, M.M.; Asefzadeh, S.; Pearson, H. Household waste behaviours among a community sample in Iran: An application of the theory of planned behaviour. Waste Manag. 2014, 34, 980-986. [CrossRef] [PubMed]

25. Karim Ghani, W.A.W.A.; Rusli, I.F.; Biak, D.R.A.; Idris, A. An application of the theory of planned behaviour to study the influencing factors of participation in source separation of food waste. Waste Manag. 2013, 33, 1276-1281. [CrossRef] [PubMed]

26. Botetzagias, I.; Dima, A.F.; Malesios, C. Extending the Theory of Planned Behavior in the context of recycling: The role of moral norms and of demographic predictors. Resour. Conserv. Recycl. 2015, 95, 58-67. [CrossRef]

27. Indhira, K.; Senthil, J.; Vadivel, S.; Appl, A.; Res, S. Awareness and attitudes of people perception towards to household solid waste disposal: Kumbakonam Town, Tamilnadu, India. Arch. Appl. Sci. Res. 2015, 7, 6-12.

28. Kumar, M.; Nandini, N. Community attitude, perception and willingness towards solid waste management in Bangalore city, Karnataka, India. Int. J. Environ. Sci. 2013, 4, 87-95.

29. Khan, S.; Kumar, A.; Malaviya, P. Assessment of Environmental Behaviour among the Urban Poor of Panjtirthi Slum, Jammu, India. Curr. World Environ. 2015, 10, 801-806. [CrossRef]

30. Jayasubramanian, P.; Saratha, M.M.; Divya, M. Perception of households towards waste management and its recycling in Coimbatore. Int. J. Multidiscip. Res. Dev. 2015, 2, 510-515.

31. Dhokhikah, Y.; Trihadiningrum, Y.; Sunaryo, S. Community participation in household solid waste reduction in Surabaya, Indonesia. Resour. Conserv. Recycl. 2015, 102, 153-162. [CrossRef]

32. Kallgren, C.A.; Wood, W. Access to attitude-relevant information in memory as a determinant of attitude-behavior consistency. J. Exp. Soc. Psychol. 1986, 22, 328-338. [CrossRef]

33. Oskamp, S.; Harrington, M.J.; Edwards, T.C.; Sherwood, D.L.; Okuda, S.M.; Swanson, D.C. Factors influencing household recycling behaviour. Environ. Behav. 1991, 23, 494-519. [CrossRef]

34. Vining, J.; Ebreo, A. What makes a recycler? A comparison of recyclers and nonrecyclers. Environ. Behav. 1990, 22, 55-73. [CrossRef]

35. Schahn, J.; Holzer, E. Studies of individual environmental concern: The role of knowledge, gender and background variables. Environ. Behav. 1990, 22, 767-786. [CrossRef] 
36. Barr, S.; Gilg, A.W. Conceptualising and analysing household attitudes and actions to a growing environmental problem. Development and application of a framework to guide local waste policy. Appl. Geogr. 2005, 25, 226-247. [CrossRef]

37. Government of India. Ministry of Home Affairs Census 2011. Available online: http:/ /www.censusindia. gov.in/ (accessed on 14 October 2016).

38. MapsofIndia.com. Map of MCD Delhi. Available online: http://www.mapsofindia.com/maps/delhi/mcdcorporation.html (accessed on 19 September 2016).

39. MRSI Socio-Economic Classification 2011. The New SEC System. Available online: http://imrbint.com/ research/The-New-SEC-system-3rdMay2011.pdf (accessed on 2 August 2016)).

40. Government of India. Solid Waste Management Rules. Available online: http://www.moef.nic.in/content/ so-1357e-08-04-2016-solid-waste-management-rules-2016 (accessed on 2 August 2016).

41. Martin, M.; Williams, I.D.; Clark, M. Social, cultural and structural influences on household waste recycling: A case study. Resour. Conserv. Recycl. 2006, 48, 357-395. [CrossRef]

42. Babaei, A.A.; Alavi, N.; Goudarzi, G.; Teymouri, P.; Ahmadi, K.; Rafiee, M. Household recycling knowledge, attitudes and practices towards solid waste management. Resour. Conserv. Recycl. 2015, 102, 94-100. [CrossRef]

43. Beall, J. Thoughts on Poverty from a South Asian Rubbish Dump: Gender, Inequality and Household Waste. IDS Bull. 1997, 28, 73-90. [CrossRef]

44. Banga, M. Household Knowledge, Attitudes and Practices in Solid Waste Segregation and Recycling: The Case of Urban Kampala Recycling: The Case of Urban Kampala. Zambia Soc. Sci. J. 2013, 2, 27-39.

45. Du, P. The Determinants of Solid Waste Generation, Reuse and Recycling by Households in Ho Chi Minh City, Vietnam; Asian Institute of Technology: Bangkok, Thailand, 1995.

46. De Feo, G.; De Gisi, S. Domestic separation and collection of municipal solid waste: Opinion and awareness of citizens and workers. Sustainability 2010, 2, 1297-1326. [CrossRef]

47. Swami, V.; Chamorro-Premuzi, T.; Snelgar, R.; Furnhamd, A. Personality, individual differences, and demographic antecedents of self-reported household waste management behaviours. J. Environ. Psychol. 2011, 31, 21-26. [CrossRef]

48. Pearson, H.; Dawson, L.; Radecki Breitkopf, C. Recycling attitudes and behavior among a clinic-based sample of low-income Hispanic women in southeast Texas. PLoS ONE 2012, 7, e34469. [CrossRef] [PubMed]

49. Desa, A.; Ba'yah Abd Kadir, N.; Yusooff, F. A study on the knowledge, attitudes, awareness status and behaviour concerning solid waste management. Procedia Soc. Behav. Sci. 2011, 18, 643-648. [CrossRef]

50. Matter, A.; Dietschi, M.; Zurbrügg, C. Improving the informal recycling sector through segregation of waste in the household-The case of Dhaka Bangladesh. Habitat Int. 2013, 38, 150-156. [CrossRef]

51. Toxics Link. An Initiative Towards Decentralised Solid Waste Management, Collaborative Efforts of RWA-Defence Colony, New Delhi and Toxics Link (An Environmental NGO); Toxics Link: New Delhi, India, 2012.

52. Rouse, J.R. Seeking common ground for people: Livelihoods, governance and waste. Habitat Int. 2006, 30, 741-753. [CrossRef]

53. Gutberlet, J. More inclusive and cleaner cities with waste management co-production: Insights from participatory epistemologies and methods. Habitat Int. 2015, 46, 234-243. [CrossRef]

54. Rockson, G.N.K.; Kemausuor, F.; Seassey, R.; Yanful, E. Activities of scavengers and itinerant buyers in Greater Accra, Ghana. Habitat Int. 2013, 39, 148-155. [CrossRef]

55. Colon, M.; Fawcett, B. Community-based household waste management: Lessons learnt from EXNORA's "zero waste management" scheme in two South Indian cities. Habitat Int. 2006, 30, 916-931. [CrossRef]

56. Fahmi, W.S.; Sutton, K. Cairo's Zabaleen garbage recyclers: Multi-nationals' takeover and state relocation plans. Habitat Int. 2006, 30, 809-837. [CrossRef]

57. Barr, S. Environment and Society: Sustainability, Policy, and the Citizen; Ashgate Publishing: Aldershot, UK, 2008.

58. Challcharoenwattana, A.; Pharino, C. Co-Benefits of Household Waste Recycling for Local Community's Sustainable Waste Management in Thailand. Sustainability 2015, 7, 7417-7437. [CrossRef]

(C) 2016 by the authors; licensee MDPI, Basel, Switzerland. This article is an open access article distributed under the terms and conditions of the Creative Commons Attribution (CC-BY) license (http:/ / creativecommons.org/licenses/by/4.0/). 